\title{
PENDAMPINGAN RAGAM PRODUK OLAHAN BERBAHAN DASAR IKAN DI DESA PAGAR BATU
}

\author{
Syahril $^{1}$ ), Syaiful Anwar ${ }^{2}$ ), Moh. Kurdi ${ }^{3}$ ) \\ 1),2) ,2) Universitas Wiraraja \\ ${ }^{1)}$ Email: syahril@wiraraja.ac.id \\ ${ }^{2)}$ Email: syaifulanwar@wiraraja.ac.id \\ ${ }^{3)}$ Email: mkurdi@wiraraja.ac.id
}

\begin{abstract}
ABSTRAK
Kegiatan pengabdian ini memiliki tujuan menciptakan produk olahan berbahan dasar ikan seperti sosis dan nugget, memasarkan produk olahan berupa sosis dan nugget kesemua lapisan masyarakat, menciptakan peluang pasar dan meningkatkan nilai tambah serta daya jual ikan. Kegiatan pengabdian dilaksanakan selama delapan bulan bersama kedua mitra, mitra pertama yang berlokasi di desa Pagar Batu Kec. Saronggi yaitu KWT "Bunga Seroja”. Metode dalam kegiatan ini adalah dengan memberikan penyuluhan kepada mitra tentang olahan ikan menjadi produk yang dapat bersaing dengan membaca peluang pasar, Memberikan demonstrasi/praktek pengolahan ikan menjadi makanan (sosis dan nugget) dengan inovasi. Melalui Program pengabdian, maka yang diharapkan adalah sebagai berikut: (1) Terampilnya untuk dalam pembuatan olahan berbahan dasar ikan dalam kemasan yang menarik, (2) Produk yang dihasilkan adalah dalam produk sosis dan nugget dalam kemasan menarik (siap dipasarkan), (3) Peningkatan penjualan sosis dan nugget. Proses penyampaian materi memanfaatkan alat peraga. Sedangkan proses praktek memanfaatkan teknologi peralatan yang telah diadakan. Sementara teknik pendampingan dan arah program pengabdian melibatkan kelompok mitra. Hasil evaluasi kegiatan pengabdian menunjukkan bahwa capaian program utama dan program pengabdian pada Kelompok Wanita Tani Bunga Seroja Desa Pagar Batu Kecamatan Saroggi Kabupaten Sumenep pengabdian dapat dilaksanakan dan terealisasi dengan baik sesuai dengan rencana dan kesepakatan semua pihak. Hasil evaluasi tingkat pemahaman tentang penguasaan materi pengabdian diperoleh hasil bahwa masyarakat sekitar $87 \%$ terjadi peningkatan wawasan, pengetahuan dan pemahaman tentang penerapan ilmu dan teknologi dalam diversifikasi produk pengolahan hasil perikanan yakni nugget dan sosis.
\end{abstract}

Kata Kunci: Olahan ikan, Kemasan, Inovasi teknologi

\section{Pendahuluan}

Ikan tongkol banyak mengandung protein yang sangat tinggi dalam memenuhi kebutuhan gizi. Kekayaan kandungan ikan tongkol diantaranya mineral, omega 3 , protein dan vitamin. Kandungan yang ada dalam ikan tongkol 22gr protein dalam setiap 100gr ikan tongkol. Memiliki kandungan omega lebih banyak dari pada ikan tawar, sedangkan kandungan mineral juga sangat banyak dalam ikan tongkol. Iodum yang terkandung dalam ikan tongkol lebih banyak 28 kali dari pada kandungan ikan tawar. Dalam ikan tongkol juga terdapat asam folat dan vitamin bahkan kandungan gizi juga sangat banyak. Selain itu, ikan tongkol mempunyai rasa yang sangat lezat bahkan ikan tongkol juga bisa menurunkan kadar kolestrol yang ada dalam tubuh manusia. Diversifikasi pengolahan ikan tongkol adalah dengan dibuat nugget dan sosis.

Bahan baku ikan dapat dijadikan beberapa macam olahan ikan, seperti sosis, dendeng, 
nugget, dan abon ikan. Sosis merupakan olahan dengan cita rasa yang gurih. Proses pembuatan sosis sangatlah mudah dan tidak membutuhkan waktu yang sangat lama. Nungget dengan bahan baku dasar ikan adalah hasil pengolahan ikan yang disajikan sebagai makanan pendamping atau sebagai lauk pauk yang sudah siap di sajikan. Dengan pengolahan bahan baku ikan menjadi nugget memiliki keuntungan, sebab duri ikan sudah dibuang dan yang digunakan hanyalah dagingnya saja. Sedangkan abon ikan merupakan jenis hasil pengolahan ikan yang diawetkan. Pada dasarnya abon mengandung gizi yang sangat baik dan bisa di konsumsi langsung atau dijadikan sebagai lauk pauk.

Masyarakat di Kabupaten Sumenep sebagian besar bekerja di sector primer, banyak peluang komoditi yang dapat digarap dan sangat menjanjikan, salah satunya sector agribisnis. Secara ekonomis hasil produk dari sektor primer yang diolah dengan menggunakan agribisnis mempunyai nilai harga dan jual yang sangat tinggi jikan dibandingkan dengan hasil produk barang primer.

Hasil produksi yang mempunyai standar sangat berdampak terhadap penambahan nilai tambah yang pada akhirnya dapat memberikan nilai jual serta keuntungan. Kelompok "BUNGA SEROJA" merupakan kelompok pengolahan yang berada di desa Pagar Batu Kecamatan Saronggi. Kelompok ini sudah mengolah berbagai makanan berbahan dasar rumput laut. Sedangkan untuk olahan ikan mereka masih mengolah hanya sekedar untuk lauk sehari-hari. Kelompok Bunga Seroja, merupakan kelompok pembudidaya rumput laut dan pengolahannya yang sebagian besar adalah perempuan. Kelompok ini terbentuk pada tanggal 20 Maret 1997, dan sampai saat iini sudah mendapat pengesahan dari Gubenur
Jawa Timur karena temasuk kelompok Utama serta sudah mengikuti berbagaimacam lomba olahan berbahan dasar rumput laut.

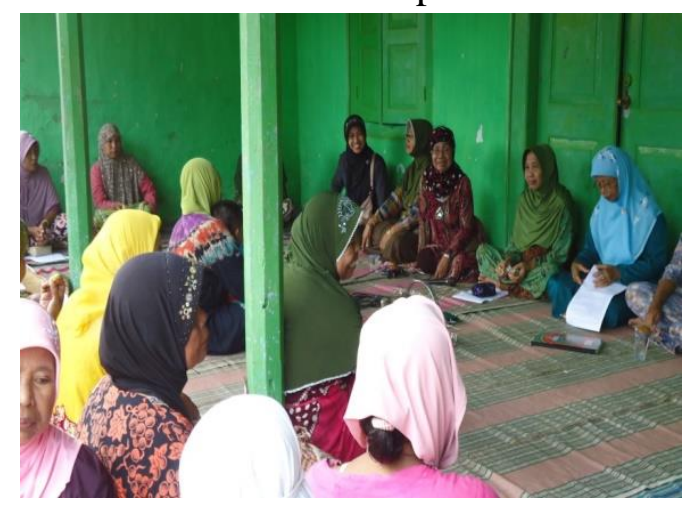

Gambar 1. KWT Bunga Seroja

\section{Metode}

Kegiatan pengabdian dilaksanakan di desa Pagar Batu Kecamatan Saronggi Kabupaten Sumenep. Pemilihan lokasi berdasarkan pada daerah pesisir yang penduduknya bermata pencaharian sebagai nelayan melalui purposive Sampling. Selain itu, pertimbangan lain karena aspek produksi, manajemen serta aspek sosial, ekonomi, budaya dan pendidikan.

Rangkaian kegiatan yang direncanakan untuk Program pengabdian sebagai berikut:

a. Sosialisasi

Sosialisasi dilakukan dimaksudkan untuk melihat kesiapan lokasi dan sasaran atau mitra sebagai potret awal daerah kegiatan.

b. Penyusunan modul pelatihan penerapan pengabdian

Modul pelatihan disusun berdasarkan atas kebutuhan program penerapan pengabdian yang meliputi, 1) teknologi proses pengolahan Sosis, dan Nugget, 2) teknik pengemasan dan 3) analisis usaha dan promosi.

c. Penyiapan sarana dan prasarana

Sarana dan prasarana yang pelu dipersiapkan pada kegiatan ini meliputi; 1) Alat dan bahan pelatihan; 2) Desain kemasan dan label; 
d. Pelaksanaan pelatihan

Pada tahap ini mitra akan dilatih untuk mengenal teknologi proses pengolahan pangan berbahan dasar ikan, mulai dari teknik penyiapan bahan dan alat, proses pengolahan, teknik pengemasan, promosi sampai kepada perhitungan usaha. Peserta yang terlibat pada kegiatan ini adalah dua anggota untuk KWT "Bunga Seroja Desa Pagar Batu Kec. Saronggi

e. Pemantauan dan refleksi

Pada saat kegiatan berlangsung, setiap tahapan proses akan dilakukan pemantauan dan dicermati/dikendalikan, sesuai dengan rencana dan tujuan yang telah ditetapkan. Bila terjadi suatu keadaan yang di luar perhitungan, maka akan segera dilakukan langkah penyesuaian dan tindakan perbaikan.

Setelah kegiatan dalam satu siklus/periode selesai, dilakukan refleksi untuk mengevaluasi apakah proses pada setiap tahapan kegiatan dan hasil telah sesuai dengan rencana. Kemudian tindak lanjut apa yang perlu dilakukan? Melalui refleksi/evaluasi ini, anggota untuk KWT "Bunga Seroja Desa Pagar Batu Kec. Saronggi dapat belajar banyak dari pengalaman. Perbaikanperbaikan yang dilakukan dari hasil refleksi/evaluasi kegiatan ini, akan menjamin terlaksananya pengabdian ini secara berkesinambungan dan berkelanjutan, untuk membentuk kemandirian secara ekonomi, sehingga tercipta suatu kelompok usaha produktif.

\section{Hasil dan Pembahasan}

Kegiatan pengabdian di Desa Pagar Batu Kecamatan Saronggi Kabupaten Sumenep dapat terlaksana dan terealisasi dengan baik sesuai dengan perencanaan dan kesepakatan semua pihak. Program yang telah dilakukan selama kegiatan pengabdian adalah memberikan pendampingan pemberdayaan partisipasi aktif kelompok masyarakat dengan transfer ilmu dan teknologi, penerapan ilmu dan teknologi melalui :

a. Pemilihan bahan baku produk olahan b. Teknik penyusunan formulasi bahan-bahan olahan hasil perikanan,

c. Teknologi pengolahan

d. Diversifikasi pengolahan hasil perikanan

e. Pengemasan.

f. Menejemen pemasaran

Berdasarkan hasil kegiatan Pengabdian, masyarakat dapat meningkatkan wawasan, ketrampilan dalam penguasaan teknologi tepat guna, peningkatan produksi, peningkatan pendapatan dan manajemen usaha. Bagi Universitas Wiraraja, pelaksanaan Pengabdian ini juga sebagai bentuk kemitraan. Bagi dosen pelaksana kegiatan ini merupakan salah wadah untuk menyebarluaskan hasil penelitian ke masyarakat sebagai perwujudan dari dharma ketiga dari Tri Dharma Perguruan Tinggi, yatu pengabdian kepada masyarakat.

Untuk mengukur tingkat keberhasilan program pengabdian ini di lakukan evaluasi terhadap keseluruhan program. Dari hasil evaluasi tentang tingkat pemahaman menunjukkan bahwa kegiatan ini memenuhi kriteria keberhasilan yang telah ditetapkan.

Hal ini dapat dilihat dari kriteria keberhasilan, yaitu: $87 \%$ terjadi peningkatan wawasan, pengetahuan dan pemahaman tentang: pemilihan bahan baku produk olahan, teknik penyusunan formulasi bahan-bahan olahan hasil perikanan, teknologi pengolahan, diversifikasi pengolahan hasil perikanan (berbagai produk dalam bentuk minced : Nugget, tempura, pengemasan dan menejemen pemasaran.

Diversifikasi Pengolahan Hasil Perikanan merupakan bahan pangan yang sangat baik dan potensial untuk memenuhi kebutuhan protein hewani bagi masyarakat. Ikan mengandung omega 3 yang berfungsi untuk pertumbuhan otak manusia. Protein yang dihasilkan dari ikan merupakan salah satu faktor penting bagi kesehatan tubuh manusia. 
Selain dalam bentuk daging ikan yang langsung dapat dikonsumsi, daging ikan juga dapat diolah menjadi nugget dan sosis. Nugget dan sosis merupakan makanan hasil perikanan favorit semua kalangan masyarakat. Mengingat masyarakat umumnya menyukai makanan yang praktis dan cepat saji.

Keberagaman produk hasil olahan perikanan menjadikan konsumsi ikan di masyarakat menjadi semakin meningkat.

a. Karakteristik Produk

Bahan baku untuk membuat nugget dan sosis berupa fillet ikan. Fillet ikan yang baik untuk bahan baku pembuatan nugget dan sosis sebaiknya memiliki tekstur daging kenyal dan berwarna putih. Untuk menjaga kestabilan rasa dan tidak cepat busuk, harus menggunakan bahan baku yang segar serta bahan-bahan pembantu yang berkualitas, diolah dengan higienis serta formulasi yang standar.

b. Karakteristik Bahan

Bahan baku dalam pembuatan nugget dan sosis adalah fillet ikan. Dalam pemilihan bahan baku filet, dapat dibuat dari beberapa jenis ikan, namun jenis ikan yang lebih baik digunakan ialah ikan tuna dan jenis ikan lainnya. Ikan tuna merupakan ikan yang sangat digemari oleh konsumen. Tingginya potensi dan kuantitas dari ikan tuna menjadikan suatu tantangan dalam mengembangkan potensi ikan tuna. Selain itu bila ditinjau dari aspek ekonomis, harga jual dari ikan tuna rendah dan belum sebanding dengan pembudidayaan ikan. Filet ikan digunakan dalam pembuatan nugget dan sosis sebagai bahan baku. Pemilihan bahan baku dengan menggunakan akan tuna merupakan salah satu pemilihan yang tepat.

Dikatakan demikian karena melihat harga jual produk segar ikan tuna dengan harga jual rendah dan ketersediaan bahan baku yang baik. Dengan karakteristik bahan baku yang mudah rusak (busuk) dan harga jual rendah dibutuhkan teknologi pengolahan yang tepat. Salah satu upaya untuk hal tersebut ialah dengan teknologi pengolahan ikan berbasis surimi dalam bentuk nugget dan sosis. Dimana dengan pengolahan ikan menjadi nugget dan sosis dapat meningkatkan nilai jual ikan, memperpanjang umur simpan ikan. Adanya alternatif pengolahan ikan tuna menjadi produk nugget dan sosis tentunya dapat meningkatkan harga jual dari ikan tuna sendiri. Bahan penunjang dari produk nugget dan sosis ialah bahan adonan yang digabungkan dengan bahan baku yaitu fillet ikan.

c. Pemanfaatan Produk

Produk nugget dan sosis merupakan salah satu bentuk diversifikasi produk hasil perikanan. Biasanya nugget dan sosis dimanfaatkan sebagai makanan penunjang atau pelengkap dari makanan pokok. Hasil olahan ini merupakan makanan yang praktis serta cepat disajikan dan kaya akan kandungan gizi menyebabkan produk alahan ini banyak digemari baik dari anak kecil hingga orang dewasa. Selain itu produk ini sifatnya gurih sehingga dapat membantu mereka menambah nafsu makan, dengan bentuk yang menarik membuat produk ini menarik konsumen untuk membelinya.

\section{d. Proses Produksi}

Proses produksi pembuatan nugget dan sosis dimulai dari penerimaan bahan baku berupa fillet ikan yang masih segar, kemudian dilanjutkan dengan proses penggilingan fillet ikan hingga berbentuk pasta, pengadukan adonan dengan penambahan bahan baku lainnya, pemasakan, pencetakan menggunakan tangan dan sendok atau garpu, penggorengan secara deep frying, penirisan di meja 
penirisan, batter, breading, ditusuk dengan sumpit, pengemasan, dan pembekuan.

\section{Simpulan}

Hasil kegiatan pengabdian yang sudah dilakukan dapat terealisasi dengan baik berkat kerjsama dari semua pihak. Pelaksaan kegiatan pengabdian mendapatkan respon yang sangat baik sehingga harapannya dapat dilanjutkan untuk kedepannya. Hasil evaluasi tingkat pemahaman tentang penguasaan materi pengabdian diperoleh hasil bahwa masyarakat sekitar $87 \%$ terjadi peningkatan wawasan, pengetahuan dan pemahaman tentang penerapan ilmu dan teknologi dalam diversifikasi produk pengolahan hasil perikanan yakni berbagai produk nugget dan sosis.

\section{Daftar Pustaka}

Hadiwiyoto, S., 1979. Hasil-Hasil Olahan Susu, Ikan, Daging dan Telur. Liberty, Yogyakarta.

Moeljanto, 1992. Pengawetan dan Pengolahan Hasil Perikanan. Penebar Swadaya, Jakarta.

Muchtadi D. 1989. Evaluasi Nilai Gizi Pangan. Departemen Pendidikan dan Kebudayaan Direktorat Jendral Perguruan Tinggi, Pusat Antar Universitas, Institut Pertanian Bogor, Bogor.

Singgih Wibowo dan Yunizal, 1998. Penanganan Ikan Segar. Balai Penelitian Perikanan Laut, Pusat Penelitian dan Pengembangan, Jakarta. Sugiri Elon, 1997. Aneka Cara Pengolahan Ikan. Dinas perikanan Jawa Barat, Bandung.

Suhardi dan Marsono, 1982. Penanganan Lepas Panen 2. Departemen pendidikan dan Kejuruan Direktorat Menengah Kejuruan, Jakarta.

Suparno, dkk., 1992. Kumpulan Hasil-Hasil Penelitian Pasca Panen Perikanan. Pusat
Penelitian dan Pengembangan Perikanan, Jakarta.

Suparno. 1998. Ilmu dan Teknologi Daging. UGM Press, Yogyakarta. 